\title{
Evaluation of the Physicochemical and Bacteriological Study of the Three Sites in Ain Sebaa-Zenata Region after the Installation of the Anti-pollution Station of the East Coast of Grand Casablanca
}

\begin{abstract}
Jalal Hdia ${ }^{1}$, Bouchra Elkhalfi ${ }^{1}$, Chaimaa Wina ${ }^{2}$, Meryem Aboudaoud ${ }^{2}$, Laila Targhalline $^{2}$, Brahim Boucherif ${ }^{3}$ and Abdelaziz Soukri ${ }^{1^{*}}$

${ }^{1}$ Laboratory of Physiopathology, Genetics Molecular and Biotechnology (PGMB), Faculty of Sciences Ain Chock, Research Center Health and Biotechnology, University of Hassan II Casablanca, Morocco.

${ }^{2}$ Higher Institute of Nursing Professions and Health Techniques (ISPITS), Casablanca, Morocco.

${ }^{3}$ Pasteur Institute, Casablanca, Morocco.

Authors' contributions

This work was carried out in collaboration among all authors. All authors contributed to the study conception and design. Material preparation, data collection and analysis were performed by authors $J H, C W, M A, L T, B B$ and BE. The first draft of the manuscript was written by authors JH and AS and all authors commented on previous versions of the manuscript. All authors read and approved the final manuscript.

\section{Article Information}

DOI: $10.9734 / A R R B / 2019 / v 34 i 130143$

(1) Dr. Manikant Tripathi, Department of Microbiology, Dr. Ram Manohar Lohia Avadh University, India. Reviewers:

(1) Fábio Henrique Portella Corrêa de Oliveira, Universidade Federal Rural de Pernambuco, Brazil. (2) Aristeidis Mertzanis, Agricultural University of Athens, Greece. Complete Peer review History: http://www.sdiarticle4.com/review-history/53616
\end{abstract}

Original Research Article

Received 15 October 2019

Accepted 25 December 2019

Published 28 December 2019

\begin{abstract}
The Moroccan coastline has been subjected exceptionally to the growth of urban agglomerations as well as to the negative effect of various industrial activities, together with the contributions of watersheds, wadis and streams that dump their sewage and the waste generated by cities and their periphery.

Aim: First of all, we carry out an evaluation of the Physicochemical, bacteriological state of the bathing water sample of the beaches of Ain Sebaâ-Zenata through the search of the bacteriological
\end{abstract}


and chemical contaminants in three sites by reinforcing them to the national norms and standards which govern the quality of the bathing water, on the other hand, we compare these results with those found before the inauguration of the anti-pollution station East of Greater Casablanca.

Study Design: Study of the seawater quality of three swimming beaches.

Place and Duration of Study: Seawater was collected on 15/04/2017 from 3 sites in the Ain Sebaa- Zenata (Douar Abdellah Belhaj Beach, El Nahla Beach, Zenata Beach) region of the city of Casablanca after the installation of the anti-pollution station.

Methodology: Our job articulates on two axes: On the one hand, the study and the analysis of the physicochemical, bacteriological quality of the seawater after the installation of EST Casablanca anti-pollution station at the level of three sites (Douar Abdellah Belhaj Beach, El Nahla Beach, Zenata Beach). On the other hand, the comparison of these results with others already carried out before the development of this station via the same characteristics: Physico-chemical, bacteriological.

Results: In the light of the acquired results, a correlation was pointed out between the Physicochemical and bacteriological examination in comparison with the standards in the three studied sites, which were previously recognized as heavily contaminated bathing areas before the installation of the station. It supports the conclusion that this anti-pollution system has a beneficial and advantageous effect and confirms its cleansing role.

Conclusion: The current physico-chemical and bacteriological results of seawater in the Ain Sebaaa - Zenata region after the installation of the anti-pollution station show a significant improvement in the quality of this bathing area as well as the beneficial effect of this plant, which performs a very considerable purification function.

Keywords: Seawater; anti-pollution station; physico-chemical; bacteriological; molecular; comparison.

\section{INTRODUCTION}

In Morocco, the marine environment plays a socio-economic role of great importance. The opening of its coast on two facades (Atlantic and Mediterranean) stretching about $3500 \mathrm{~km}$ of coastline [1]. On the Mediterranean Sea, from Cap Spartel to Saïdia, the coast stretches for 500 $\mathrm{km}$ and just under $3,000 \mathrm{~km}$ on the Atlantic, from Cap Spartel to Lagouira offers a strategic position [2] Indeed, the Moroccan coasts introduce the advantage of being among the richest in the world with a broad diversity of ecosystems [3]. Thus, a good part of this area constitutes a privileged place for the installation of many agglomerations and industrial units.

As a result, approximately $60 \%$ of the population and more than $70 \%$ of industries are concentrated in the coastal urban centres. Thus, these ribs are exposed to chronic contamination, due to direct discharges, mainly of domestic and industrial origin that is discharged without any prior treatment. The Casablanca region is located on the Atlantic coast, in the central west of Morocco and covers an area of $1,140.54 \mathrm{~km}^{2}$, which offers it a strategic position. In recent years, it has experienced critical fishing and seaside activities, which has led to a high level of microbial pollution in seawater [1].
To reduce marine pollution due to industrial and urban discharges in the Casablanca region, which is a highly industrialized and urbanized city where most of the country's socio-economic activities are concentrated, namely industry, fishing, navigation ... Lydec has inaugurated an anti-pollution station (SAP-EST) in Grand Casablanca, putting into service a system of domestic and industrial wastewater treatment [4].

\section{MATERIALS AND METHODS}

\subsection{Choice of Sampling Sites}

The selection of sampling sites was based on the geographical coordinates of the previous study [5] and their representativeness of the environment concerning the sources of pollution. We have chosen: Site 1: Beach of Douar Abdellah Belhaj in front of the Sherifian society. (33 $\left.{ }^{\circ} 7^{\prime} 11^{\prime \prime} \mathrm{N}-7^{\circ} 32^{\prime} 57^{\prime \prime} \mathrm{W}\right)$; Site 2: Beach of EL

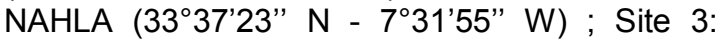
Beach of ZENATA I (33 $\left.38^{\prime} 6^{\prime \prime} \mathrm{N}-7^{\circ} 30^{\prime} 38^{\prime \prime} \mathrm{W}\right)$.

\subsection{Samples}

The samples were taken on 15/04/2017. We place ourselves, equipped with a barrel of 5 litres sterile, in the wave breaking zone against the current, then we immerse in the water at $20 \mathrm{~cm}$. 


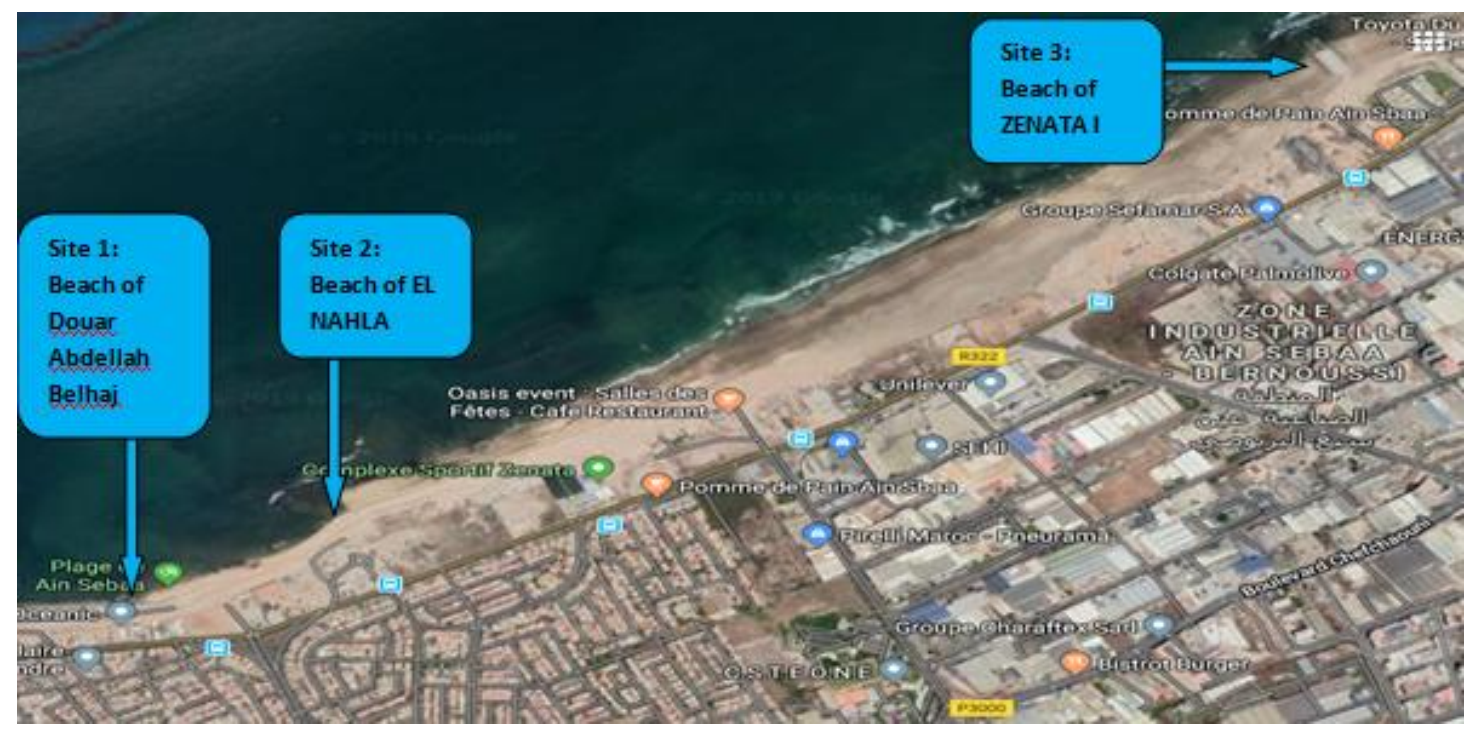

Fig. 1. Geographic location of sampling sites (Google Heart, visited on 21/11/2019)

The surface $[6,7]$ is filled in three-quarters and closed immediately. The samples were sent from the sampling sites in a cooler $\left(4\right.$ to $\left.5^{\circ} \mathrm{C}\right)$ to the laboratory [8].

\subsection{Analysis Techniques}

\subsubsection{Physico-chemical parameters}

For each sample, on the site, we measured water temperature, electrical conductivity, $\mathrm{pH}$, turbidity, water salinity and dissolved oxygen using a Mettler Toledo multiparametric measuring instrument. Other analyzes such as BOD5 (Biological Oxygen Demand in 5 days) were performed in the laboratory as described in the international standards ISO 5815-1 [9] and the determination of nitrite by the method of Zambelli [10].

\subsubsection{Bacteriological parameters}

The search and enumeration of bacteria of faecal origin (total coliforms on TTC Tergitol medium, faecal coliforms on TTC Tergitol medium and faecal streptococci medium on Slanetz and Bartley medium) and the detection of pathogenic bacteria (spores of Clostridium Sulfito-reducers on SPS medium and Salmonella on SS and Hektoen medium) were carried out by the membrane filtration technique $(0.45 \mu \mathrm{m})$ using the standard method ISO 6579: 1993 [11,12].

\subsubsection{Molecular parameters}

DNA extraction is carried out by the rapid method of Boiling preparation [13] with small volumes, the molecular confirmation of Salmonella is carried out by the gene amplification technique (PCR)nestled in a 1Kb DNA fragment of the chromosome-specific InvA invasion gene (Salmonella Typhimurium No. M90846.1) using the F-5'accacgctttttttcgtctttcgtctg3' and antisense R-5gagactacgcaaga3 According to a program that contained 35 cycles and a hybridization of $620 \mathrm{C}:\left(95^{\circ} \mathrm{C}-5^{\prime} /\left(94^{\circ} \mathrm{C}, 45^{\prime \prime}\right)\right.$ $\left.\left.62^{\circ} \mathrm{C}, 30^{\prime \prime} / 72^{\circ} \mathrm{C}, 1^{\prime}\right) \times 35 / 72^{\circ} \mathrm{C}-10^{\prime} / 4^{\circ} \mathrm{C}-5^{\prime}\right)$ [14].

\section{RESULTS AND DISCUSSION}

\subsection{Physico-chemical Results}

According to the physicochemical study of the three sites: we were able to deduce that the parameters are very close to the recommended standards [15], specific parameters gave acceptable results in relation with the guide values, such as the $\mathrm{pH}$ (Fig. 3) which varies between 7.5 and 8.3 and according to Šolić and Krstulović - 1992, these values are influenced by the carbon dioxide content of the atmosphere (measured as $\mathrm{CO} 2$ partial pressure (pCO2)) which affects the content of the ocean surface, and in return affects the $\mathrm{pH}$ of seawater [16]. The temperature (Fig. 2) has known values of 18.2 and $19.3^{\circ} \mathrm{C}$ which remains around the optimum value; moreover, the temperature measurement makes it possible to correct other parameters of water analysis whose values are related to the temperature (conductivity and salinity in particular). Studies show that anthropogenic $\mathrm{CO} 2$ 
increasing leads to ocean and atmospheric warming and ocean acidification (Caldeira 2005), Caldeira K (2005) and Hans-O (2014) proposed a model suggesting that the seawater temperature continues to rise from 2.0 to $4.5^{\circ} \mathrm{C}$ $[17,18]$ and that by the end of the century, the $\mathrm{pH}$ decreases by 0.4 unit [19]. While we observed an increase in the levels of each turbidity (Fig. 5) (22 to 32 , standard: 0.5 to 10 UNT) and conductivity (Fig. 4) (minimum: $56 \mathrm{~ms} / \mathrm{cm}$, maximum: 60.2 $\mathrm{ms} / \mathrm{cm}$ ), which indicates significant mineralization of seawater. Yet, the conductivity gives an appreciation of the ion content of seawater and therefore controls its electrical capacity [20], however, this increase in turbidity coincided with the completion of the rainy season, this increase has been attributed to the flow of rivers and muddy runoff that discharged their contents into the shoreline during the study period, and the installation in this region of large sewage collectors in Casablanca city injecting water from these coasts with faecal waste and nutrients, it should be noted that very turbid water prevents the penetration of light and reduces the effect of microbial destruction by UV light from the sun [21], which explains the presence of bacteria and their resistance [22] as well as their high presence during the winter. Concerning salinity (Fig. 6), values of $40 \mathrm{mg} / /$ were reported at site 2, $41 \mathrm{mg} / \mathrm{I}$ in site 1 and $42 \mathrm{mg} / \mathrm{l}$ in site 3; many authors talk about climate change that has a direct impact on the whole land including the oceans, among the filed scenarios is that are expected is that the salinity changes due to the global warming phenomenon, the reduction of salinity or its increase depends on the latitude of the region [23]. This explains the variations in salinity found in the sites studied. BOD5 (Fig. 8), which represents a moderately high bacterial load raging between $3 \mathrm{mg}$ of $\mathrm{O} 2 / \mathrm{l}$ at site 1 and $60 \mathrm{mg}$ of $\mathrm{O} 2 / / 1$ at site 2, this test is, currently, called the closed bottle; however, there is much scientific research on BOD5 in freshwater and wastewater [24], unlike seawater, where there has been little information of BOD5, which most of the dissolved organic matter is resistant to microbial oxidation [25]. There was also a slight increase of nitrites (Fig. 9) of the order of 0.088 $\mathrm{mg} / \mathrm{I}$, however BRANDHORST (1959) stated that the high concentrations of nitrite in water are a result of the lack of nitrifying bacteria [26], confirming the presence of bacteria in all the seawater sites studied with a higher rate in the site 3 indicating to a higher bacterial load. We also recorded a decrease in dissolved oxygen values (Fig. 7) up to $61 \%$ in site 2 and $72 \%$ in site 1 and despite this decrease, it remains significant and showing poor oxygenation in both sites, on the other hand, proper relative oxygenation has been reported as high as $92 \%$ for site 3. The consumption of dissolved $\mathrm{O} 2$ in seawater provides valuable information concerning the biological consumption of living organisms [27]; which converges towards the possibility of the presence of microorganisms in the seawater of these sites. Therefore, and according to the current Physico-chemical results of the sites studied after the installation of the EST anti-pollution station of Casablanca, there is a marked improvement of all the values measured under the same spatiotemporal conditions compared to the results found in a subsequent study we conducted prior to the installation of this sewage treatment plant project [5]. This proves its effectiveness in restoring the parameters of the quality control of seawater for swimming.

\subsection{Bacteriological Results}

As for the bacteriological results at the three sites, the values obtained were consistent with the guideline values for faecal coliforms with 60 CFU / $100 \mathrm{ml}$ in site 1, $23 \mathrm{CFU} / 100 \mathrm{ml}$ in site 2 and 45 CFU. / $100 \mathrm{ml}$ in site 3 (Table 1), and for faecal streptococci whose count varied between $1 \mathrm{CFU} / 100 \mathrm{ml}$ in the site 1,2 and $8 \mathrm{CFU} / 100 \mathrm{ml}$ in site 3 (Table 1). That proves that all the sites studied are largely compliant with the national standard (NM 03.7.200), transposed from the European Directive (76/160 / EEC) and the WHO / UNEP Directives and applicable to the sanitary surveillance of marine bathing waters [28] which tolerates guideline values (GV) in the order of $100 \mathrm{CFU}$ in $100 \mathrm{ml}$ of filtered seawater for both faecal coliforms and fecal streptococci, conversely, imperative values (VI) per $100 \mathrm{ml}$ of filtered seawater, they are of the order of 2000 CFU / $100 \mathrm{ml}$ for faecal coliforms and $400 \mathrm{CFU} /$ $100 \mathrm{ml}$ for faecal streptococci (Table 2). In parallel with the enumeration of bacteria, which, allows the assessment of the quality of the bathing water of the monitored beaches. $W$ have isolated other bacterial strains such as total coliforms and sulfite-reducing Clostridium to get an idea about the bacterial load and to date the biological pollution.

On the other hand, the isolation of Salmonella is a part of the protocol to verify the quality of bathing areas because the presence of only one of these bacteria condemns the closure of the concerned beach to avoid the risk of bathers contamination. We have noted in the study areas 
that total coliform enumeration ranged from 40 CFU / $100 \mathrm{ml}$ in site 2, $73 \mathrm{CFU} / 100 \mathrm{ml}$ in site 3 and $140 \mathrm{CFU} / 100 \mathrm{ml}$ in site 1 with the absence of certain pathogenic germs such as Clostridium sulfite-reducer spores and Salmonella (Table 1). Furthermore, and based on these bacteriological results which are currently found, it is clear that they show a considerable decrease in all indicators of faecal contamination by the enumeration of both faecal coliforms and faecal streptococci that have become compliant with national standards. (NM 03.7.200) however, before the installation of the anti-pollution station in the EST of Casablanca, the bacteriological quality of this region was deteriorated as a result of untreated wastewater, which shows the beneficial effect of the antipollution station on the quality of seawater bathing areas of the region of Ain Sebaa Zenata.

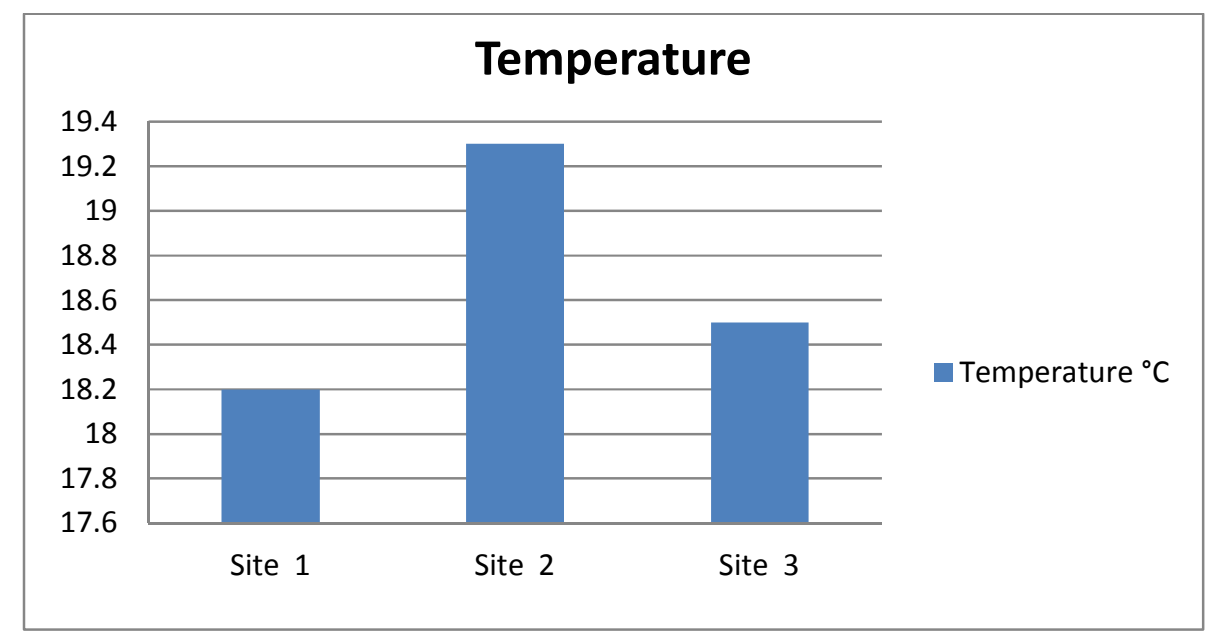

Fig. 2. Graphical representation of seawater temperature at sites 1, 2, 3

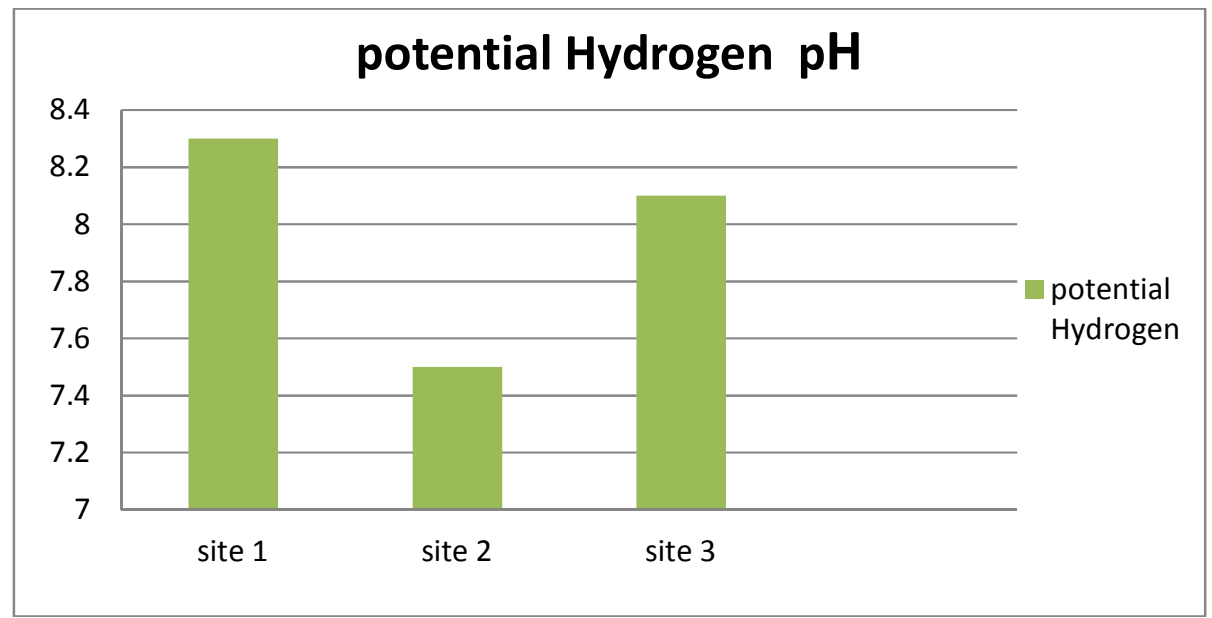

Fig. 3. Graphical representation of the $\mathrm{pH}$ of seawater at sites 1, 2, 3

Table 1. Enumeration of bacteria isolated in site 1, 2 and 3

\begin{tabular}{llll}
\hline Microbiological parameters & Site 1 & Site 2 & Site 3 \\
\hline Fecal coliforms UFC/100 ml & 60 & 23 & 45 \\
Fecal streptococci UFC/100 ml & 1 & 1 & 8 \\
Total coliforms UFC/100 ml & 140 & 40 & 73 \\
Clostridium sulfite-reducing spores UFC/100 ml & 0 & 0 & 0 \\
Salmonella UFC/100 ml & 0 & 0 & 0 \\
\hline
\end{tabular}




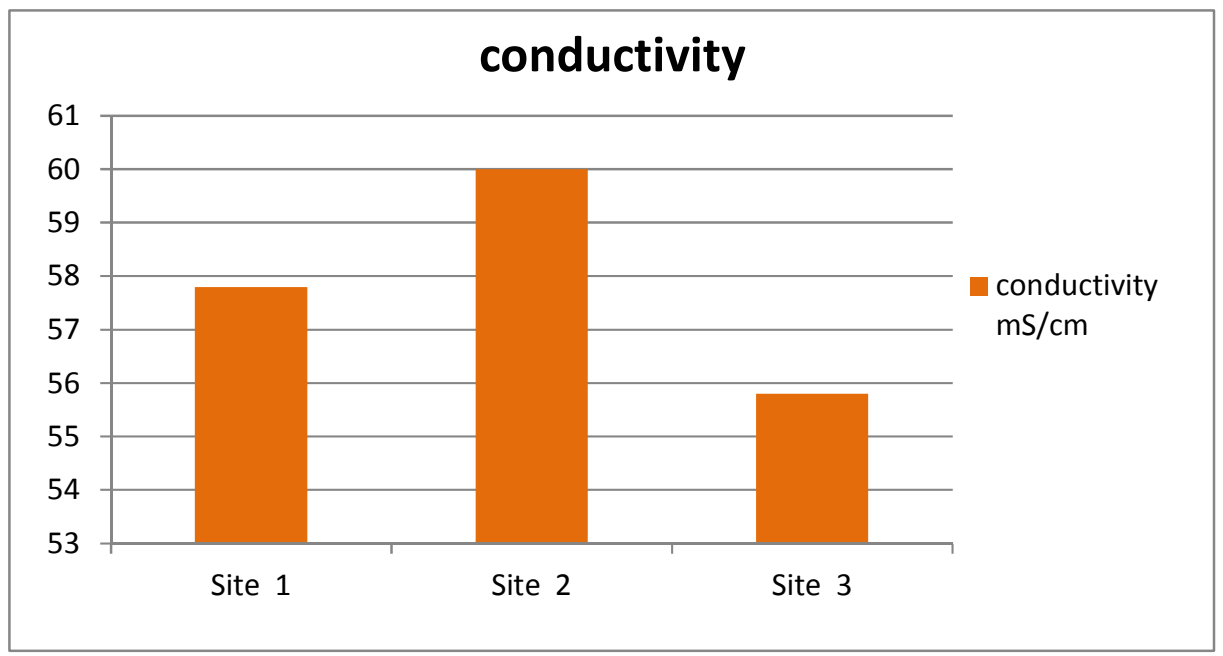

Fig. 4. Graphical representation of seawater conductivity at sites 1, 2, 3

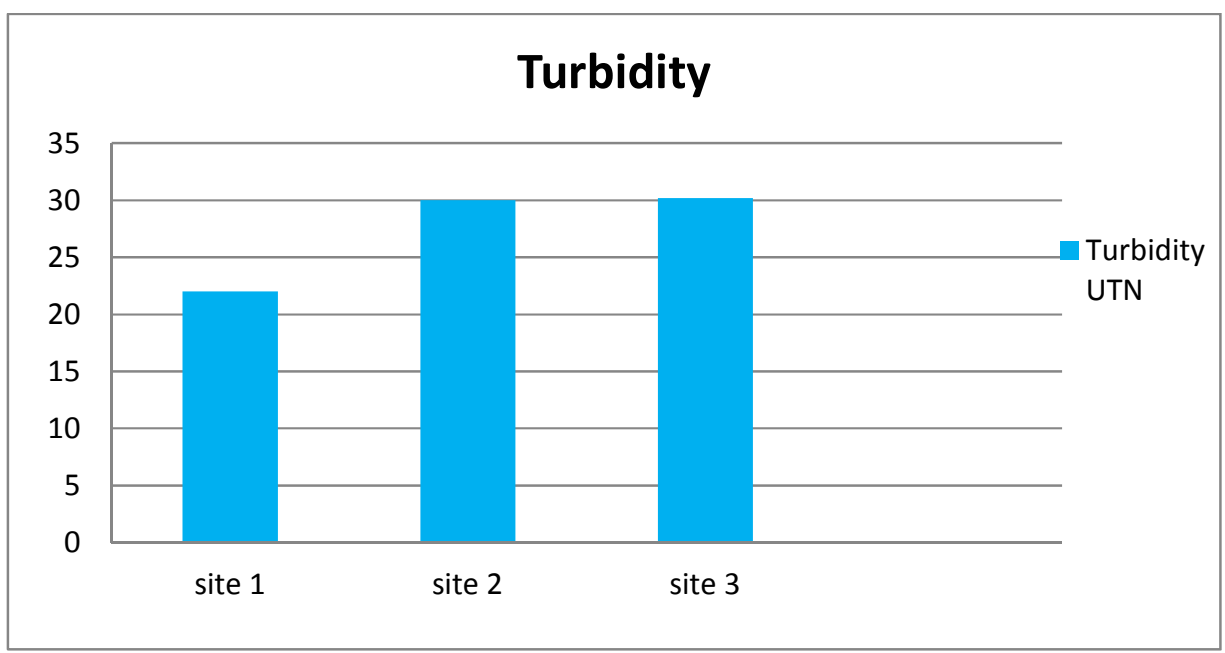

Fig. 5. Graphical representation of seawater turbidity at sites 1, 2, 3

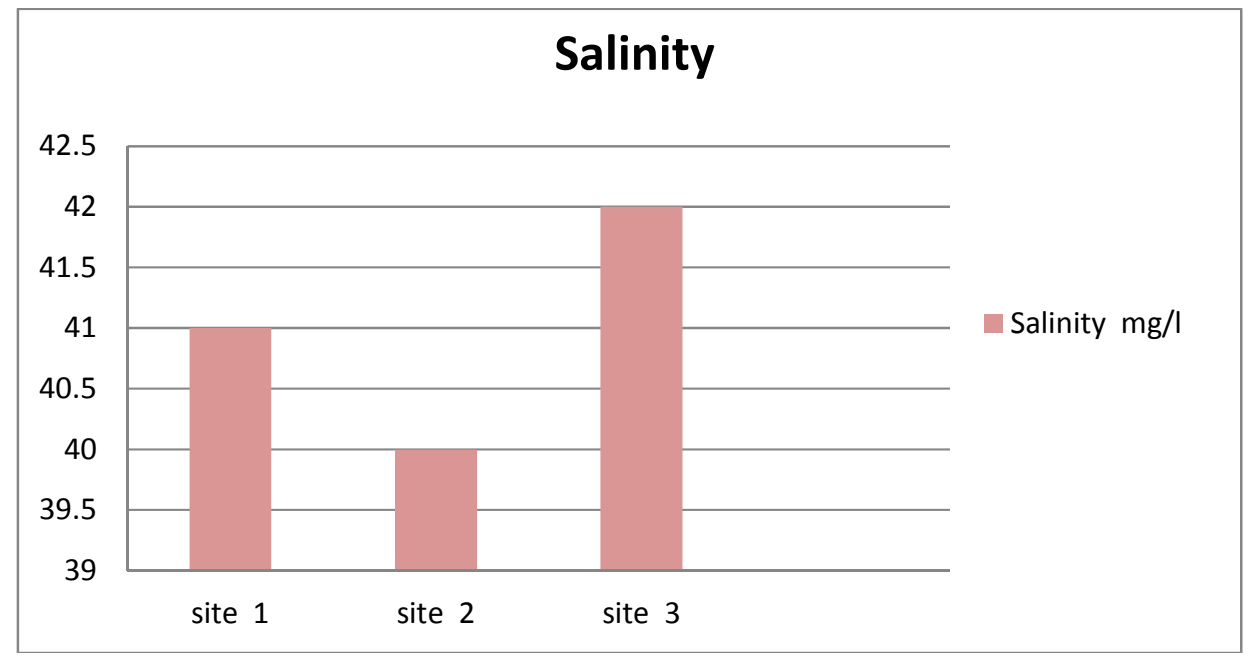

Fig. 6. Graphical representation of seawater salinity from sites 1, 2, 3 


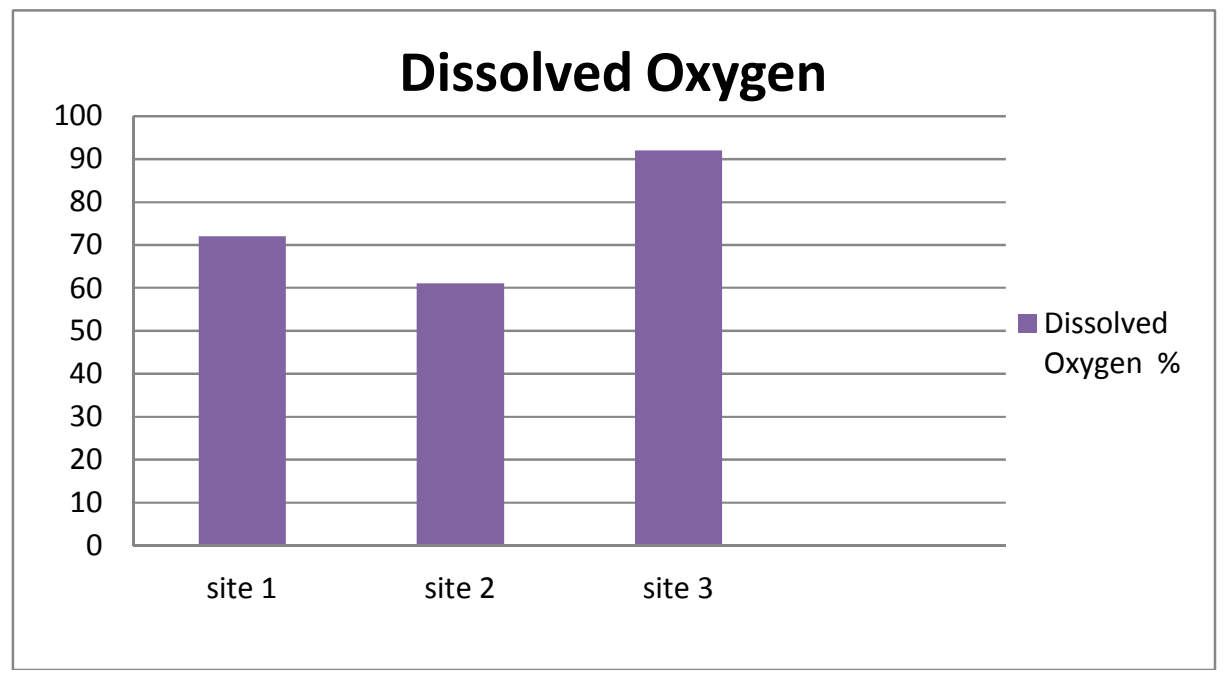

Fig. 7. Graphical representation of dissolved oxygen in seawater from sites 1, 2, 3

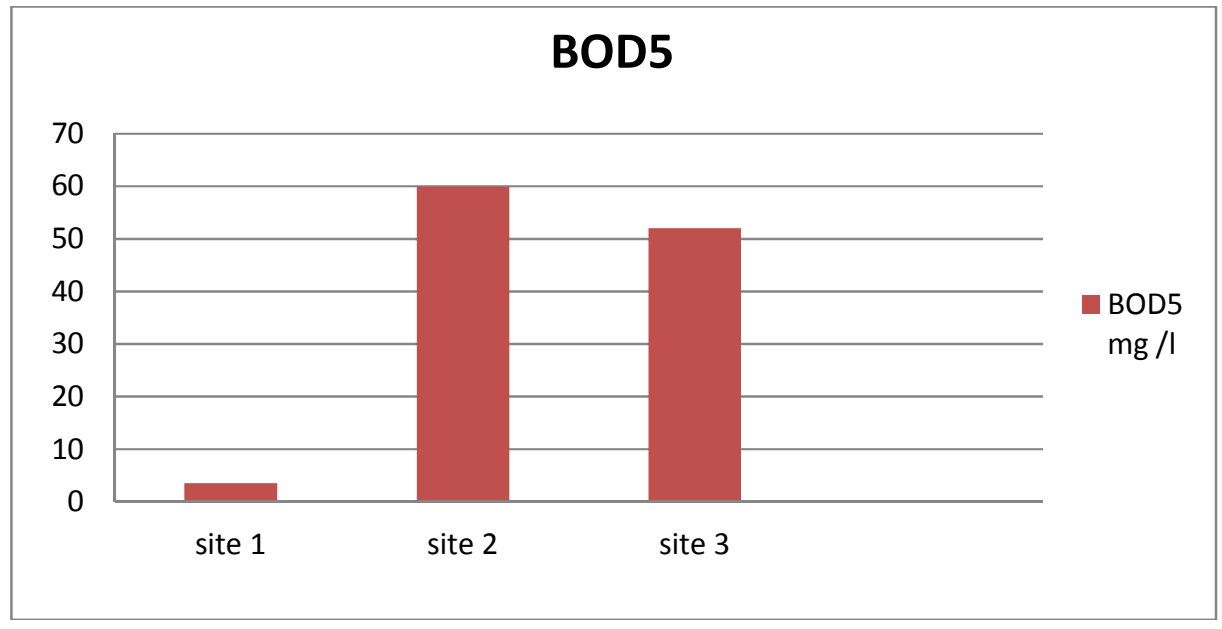

Fig. 8. Graphical representation of the BOD5 of seawater from sites 1, 2, 3

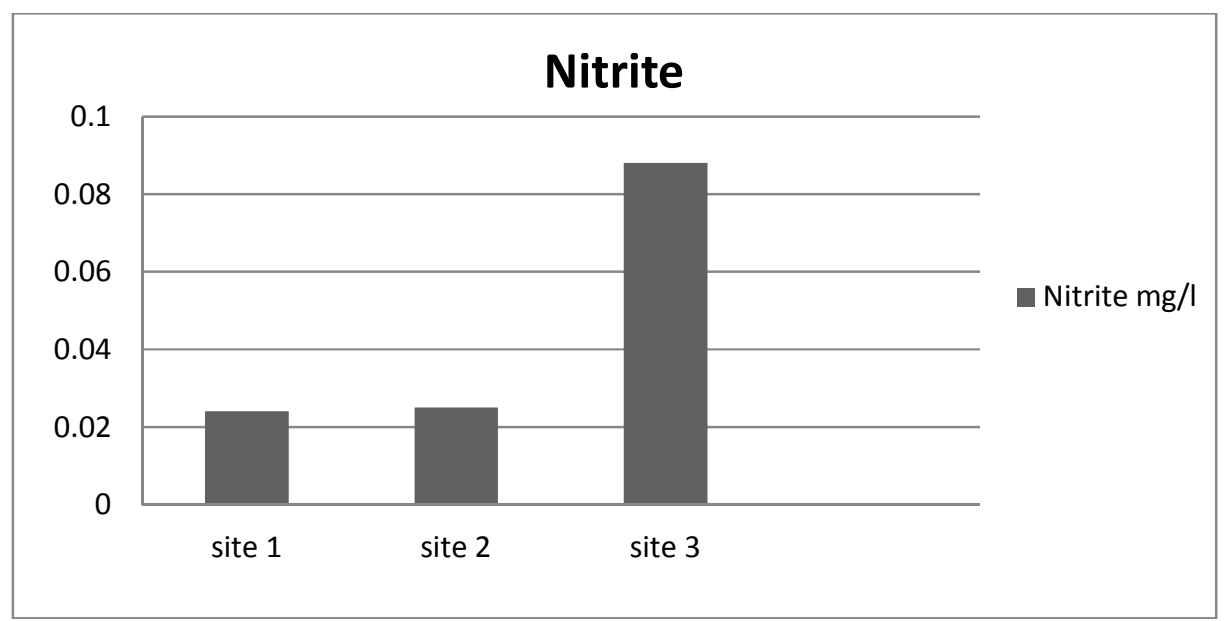

Fig. 9. Graphical representation of nitrites in seawater from sites 1, 2, 3 
Table 2. Moroccan standards (NM 03.7.200) for the bacteriological quality of marine bathing waters

\begin{tabular}{lll}
\hline Microbiological parameters & Guide values (VG)/100 $\mathbf{~ l l}$ & Mandatory values (VI) / 100 $\mathbf{~ m l}$ \\
\hline Fecal coliforms & 100 & 2000 \\
Fecal Streptococci & 100 & 400 \\
\hline
\end{tabular}

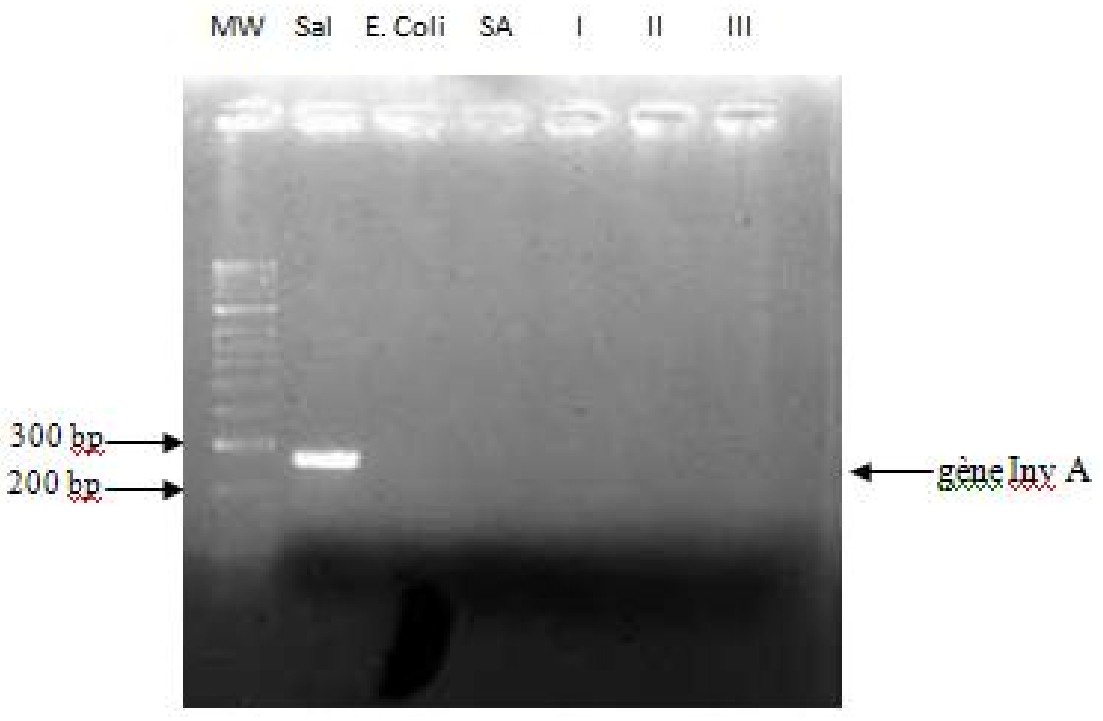

Fig. 10. Agarose gel electrophoresis $1.5 \%$ of the invA gene ( $275 \mathrm{bp})$

MW: Size marker (100 bp Leader), I: Site 1, II: site 2, III: site 3, E. coli: Escherichia strain coli, Sal: Salmonella strain typhimurium DT 104, SA: Staphylococcus strain aureus

However, to better verify the bacteriological results, we propose to carry out a molecular detection and identification study through PCR (Polymerase Chain Reaction). This study focuses mainly on the search for germs that are difficult to cultivate, such as Salmonella, since standard bacteriological research tests have given negative results. In this perspective, many studies have proved the effectiveness of the method of molecular biology by PCR for the rapid and promising search for Salmonella [29,30] as the classical identification techniques through the demonstration of deceptive biochemical traits. That can last three days to have a complete identification, yet, it is needed to look for another alternative.

\subsection{Molecular Results}

The results of the PCR were presented on the agarose gel. The $275 \mathrm{bp}$ band provided for the Salmonella-positive control DNA is well-present, and there is no band for the DNA of the two negative controls (E. coli, Staph) which suggests that the PCR was conducted in right conditions, without contamination. As a result, the reliability of the results is entirely guaranteed. Besides, numerous studies have proved the efficacy of the search speed of pathogenic germs by molecular techniques such as PCR instead of using conventional techniques [31,32] less promising and longer for identification. Some germs are difficult to cultivate.

Regarding the three sites studied, we find that there is no Inva gene band on the electrophoresis gel, which means the absence of Salmonella Typhimurium germ searched by PCR. In sites 1, 2 and 3 it was previously declared positive by the same technique in site 2 and 3 [5] which further confirms the beneficial effect of environmental protection after the inauguration of this anti-pollution station in the EST area of Grand Casablanca.

\section{CONCLUSION}

Since the commissioning of the eastern coast of East Casablanca (SAP-Est) anti-pollution system 
in 2015, wastewater from the entire area stretching from the port of Casablanca to the Mohammedia City, has been pre-treated before being discharged into the sea; this study is the first of its kind to include results after the inauguration of this station and at the same time relying on other subsequent and alarming results that previously demonstrated the seriousness of bacterial pollution as well as the degradation of the Physico-chemical quality which beaches were suffering from prior to this treatment project. The study, in one hand, allowed us to monitor the physicochemical and bacteriological quality of the seawaters in this region after the installation of this station, and on the other hand to verify the proper functioning of the wastewater treatment plant by comparing the results currently found during this study with those already achieved before the establishment of the station. In general, it has been found in our study that the seawaters of Zenata region comply with Moroccan standards. Concerning the physicochemical quality, we observed a decrease in the levels of each of the turbidity, conductivity, BOD5 and nitrites compared to the values obtained before the installation of SAP. At the level of the bacteriological study of the three sites, we were able to deduce that the values obtained for faecal coliforms and faecal streptococci following the guide values, which mean the absence of faecal contamination, we also noted the absence of pathogenic germs such as Salmonella and Clostridium- Sulfitereducers.

\section{ACKNOWLEDGEMENTS}

I would like to thank Professor Soukri Abdelazize and Professor El khalfi Bouchra for their invaluable help in writing this article. I would also like to thank Dr Brahim Boucherif, Chaimaa Wina, Meryem Aboudaoud and Laila Targhalline for the practical part in which they have contributed in a professional way to the success of all the analyses carried out during this study.

\section{COMPETING INTERESTS}

Authors have declared that no competing interests exist.

\section{REFERENCES}

1. Chaouay A, Bazzi L, Hilali M, Alla AA, Mouaden KE. Etude de la contamination bactériologique de la Baie d'Agadir. $2014 ; 7$.
Available:https://www.researchgate.net/pro file/A_Chaouay/publication/291698065_21JMES-S2-

Chaouay1/links/56a53c0908ae1b6511329

56b/21-JMES-S2-Chaouay1.pdf

2. Abdellah Laouina. littoral marocain et changement climatique; 2010.

Available:https://www.ires.ma/wpcontent/u ploads/2015/11/littoral_marocain_et_chang ement_climatique_0.pdf.

3. Fem, Décenie des nations unies pour la biodiversité, Pnud. Cinquième rapport national sur la mise en oeuvre de la convention sur la diversité biologique; 2014.

Available: https://www.cbd.int > doc > world > ma-nr-05-fr

4. Grand Casablanca: Le système antipollution du littoral Est opérationnel. La Nouvelle Tribune; 2015.

Available: https://Int.ma , grandcasablanca-le-systeme-antipollution-dulittoral-est-op

5. Hdia J, Khalfi BE, Boucherif B, Soukri A. A physicochemical, bacteriological and molecular evaeluation state of the coast of Ain Sebaa-Zenata in Morocco. International Journal of Scientific Engineering and Research (IJSER). 2018; 6(5):4.

6. Isabelle Amouroux (IFREMER) et Didier Claisse (IFREMER). Guide

Echantillonnage Milieu Marin; 2015.

Available:https://www.aquaref.fr/system/file s/Guide_Echantillonnage_Milieu_Marin_vf 2015

7. Kacar A, Omuzbuken B. Assessing the seawater quality of a coastal city using fecal indicators and environmental variables (Eastern Aegean Sea). Mar. Pollut. Bull. 2017;123(1-2):400-403.

DOI: 10.1016 / j.marpolbul.2017.08.052

8. Perošević A et al. The impacts of seawater physicochemical parameters and sediment metal contents on trace metal concentrations in mussels - A chemometric approach », Environmental Science and Pollution Research. 2018;25(28):28248-28263. DOI:https://doi.org/10.1007/s11356-0182855-8

9. Jouanneau $S$ et al. Methods for assessing biochemical oxygen demand (BOD): A review. Water Research. 2014;49:62-82. DOI:https://doi.org/10.1016/j.watres.2013.1 0.066 
10. Yücel $Y$, Çam AR. Assessment of industrial pollution effects in coastal seawater (Northeastern Mediterranean Sea) with chemometric approach. International Journal of Environmental Analytical Chemistry. 2019;1-18.

DOI:https://doi.org/10.1080/03067319.201 9.1660877

11. Lušić DV, et al. Evaluation of equivalence between different methods for enumeration of fecal indicator bacteria before and after adoption of the new Bathing Water Directive and risk assessment of pollution. Marine Pollution Bulletin. 2013;73(1):252257.

DOI: 10.1016 / j.marpolbul.2013.05.012

12. Jimenez $M$, Chaidez $C$. Improving salmonella determination in Sinaloa rivers with ultrafiltration and most probable number methods. Environ Monit Assess. 2012;184(7):4271-4277.

DOI: 10.1007 / s10661-011-2262-9

13. Teeranaipong $P$, Tia T, Putaporntip C. A simple and efficient DNA extraction from respiratory samples for $\mathrm{PCR}$ detection of Pneumocystis jirovecii. Chulalongkorn Medical Journal. 2018;62(4):725-736.

DOI: $10.14456 / \mathrm{clmj} .2018 .9$

14. Karraouan B, Bouchrif $B$. Prévalence et gènes de virulence des Salmonella isolées des eaux superficielles de l'oued khoumane, Maroc. Lebanese Science Journal. 2014;15(2):3.

15. Dheenan PS, Jha DK, Vinithkumar NV, Ponmalar AA, Venkateshwaran $P$, Kirubagaran R. Spatial variation of physicochemical and bacteriological parameters elucidation with GIS in Rangat Bay, Middle Andaman, India. Journal of Sea Research. 2014;85:534-541.

16. Šolić $M$, Krstulović $N$. Separate and combined effects of solar radiation, temperature, salinity, and $\mathrm{pH}$ on the survival of faecal coliforms in seawater. Marine Pollution Bulletin. 1992;24(8):411416.

DOI:https://doi.org/10.1016/0025326X(92)90503-X

17. Pörtner HO. Synergistic effects of temperature extremes, hypoxia, and increases in $\mathrm{CO}_{2}$ on marine animals: From Earth history to global change. J. Geophys. Res. 2005;110(C9):C09S10.

DOI:https://doi.org/10.1029/2004JC002561

18. Hans O. Pörtner, David M. Karl. Ocean Systems. Cambridge University Press,
Cambridge, Royaume-Uni et New York, NY, USA; 2014.

DOI: $10.1017 / C B O 9781107415379.011$

19. Caldeira K, Wickett ME. Anthropogenic carbon and ocean pH. Nature. 2003;425 (6956):365-365.

20. Pawlowicz R. The electrical conductivity of seawater at high temperatures and salinities », Desalination. 2012;300:32-39. DOI:https://doi.org/10.1016/j.desal.2012.06 .001

21. U. S. Environmental Protection Agency, Office of Atmospheric Programs, Climate Change Division, et Washington D.C. Endangerment and cause or contribute findings for greenhouse gases under section 202(a) of the Clean Air Act: EPA's Response to Public Comments; 2009.

Available:https://www.epa.gov> ghgemissions > endangerment-a

22. Momba M. Regrowth and survival of indicator microorganisms on the surfaces of household containers used for the storage of drinking water in rural communities of South Africa. Water Research. 2002;36(12):3023-3028. DOI:https://doi.org/10.1016/S00431354(02)00011-8

23. Bautista-Chamizo E, Sendra M, Cid Á, Seoane M, Romano de Orte M, Riba I. Will temperature and salinity changes exacerbate the effects of seawater acidification on the marine microalga Phaeodactylum tricornutum? Science of the Total Environment. 2018;634:87-94.

DOI: 10.1016 / j.scitotenv.2018.03.314

24. Gupta AK, Gupta SK, Patil RS. Statistical analyses of coastal water quality for a port and harbour region in India. Environ Monit Assess. 2005;102(1-3):179-200.

DOI: https://doi.org/10.1007/s10661-0056021-7

25. Ogawa H. Production of refractory dissolved organic matter by bacteria. Science. 2001;292 (5518):917-920.

DOI: 10.1126 / science.1057627

26. Carlucci AF, Hartwig EO, Bowes PM. Biological production of nitrite in seawater. Marine Biology. 1970;7(2):161 166.

DOI: https://doi.org/10.1007/BF00354921

27. Nakayama N, Obata H, Gamo T. Consumption of dissolved oxygen in the deep Japan Sea, giving a precise isotopic 
fractionation factor. Geophys. Res. Lett. 2007;34(20):L20604.

DOI:https://doi.org/10.1029/2007GL02991 7

28. Secrétariat d'Etat auprès du Ministre de l'Energie, des Mines et du Développement Durable, et chargé du Développement Durable. Surveillance de la qualité des eaux de baignade des plages du Royaume Rapport national Edition: 2018.

Available:https://www.environnement.gov. ma/images/Mde_PDFs/RAPPORT\%20NA TIONAL\%2023062018.pdf.

29. Mollasalehi H, Yazdanparast R. Development and evaluation of $a$ novel nucleic acid sequence-based amplification method using one specific primer and one degenerate primer for simultaneous detection of Salmonella Enteritidis and Salmonella Typhimurium, Analytica Chimica Acta. 2013;770(169 174).
DOI:https://doi.org/10.1016/j.aca.2013.01.0 53

30. Zhang G, Brown EW, González-Escalona $\mathrm{N}$. Comparison of real-time PCR, reverse transcriptase real-time PCR, loopmediated isothermal amplification and the FDA conventional microbiological method for the detection of Salmonella spp. in produce. Appl. Environ. Microbiol. 2011;77(18):6495-6501.

DOI: 10.1128 / AEM.00520-11

31. Zhou L, Pollard AJ. A novel method of selective removal of human DNA improves PCR sensitivity for detection of Salmonella typhi in blood samples. BMC Infect. Dis. 2012;12:164.

DOI: 10.1186 / 1471-2334-12-164

32. Gugliandolo C, Lentini V, Spanò A, Maugeri TL. Conventional and molecular methods to detect bacterial pathogens in mussel. Letters in Applied Microbiology. 2011;52(1):15-21.

DOI: 10.1111 / j.1472-765X.2010.02959.x

(c) 2019 Hdia et al.; This is an Open Access article distributed under the terms of the Creative Commons Attribution License (http://creativecommons.org/licenses/by/4.0), which permits unrestricted use, distribution, and reproduction in any medium, provided the original work is properly cited.

Peer-review history:

The peer review history for this paper can be accessed here: http://www.sdiarticle4.com/review-history/53616 